Iqtishaduna, Vol. 12 No. 2 Desember 2021

pISSN 20879938 | eISSN 26559714

online: https://journal.uinmataram.ac.id/index.php/iqtishaduna

\title{
ANALISIS PENGARUH VARIABEL DER, NPM DAN ROE TERHADAP HARGA SAHAM PERUSAHAAN SEKTOR KEUANGAN
}

(Studi Pada Indeks LQ-45 Di Bursa Efek Indonesia Periode 2013-2018)

\author{
La Ode Rahmat Putra Rustaman \\ Universitas Gunadarma \\ laoderahmatputrar@gmail
}

\begin{abstract}
The main purpose of trading for the investors in capital market is a profit. This study aims to analyze the influence of fundamental factors such as debt to equity ratio, net profit margin, and return on equity on stock price. This study uses annual sample with the data from 2013-2018. Population of this research is 7 Factories, yet getting 7 factories after passing through the purposive sampling. This study uses analysis techniques of linear regression multiple which is a technique for knowing the entanglement of fundamental variables in the company to stock price in financial sector. The results of the study show that model of linear multiple regression equation is LN_Stock Price $(\mathrm{Y})=8,067-0,145$ Debt to Equity Ratio $+4,759$ Net Profit Margin $+1,961$ Return On Equity and adjusted $R_{2}$ value of 67,2 percent. Simultaneously these variable debt to equity ratio, net profit margin, and return on equity are significant to stock price, can be observed in value of probability is $0,000<0.05$. Whereas, partially these variables debt to equity ratio and net profit margin have effects significantly on stock price as well as return on equity have effects insignificant on stock price all the same.
\end{abstract}

Keywords : Fundamental Factors, Debt to Equity (DER), Net Profit Margin (NPM), Return on Equity (ROE), Stock Prices.

\section{PENDAHULUAN}

Pasar modal Indonesia memberikan sarana bagi perusahaan untuk mendapatkan sumber dana dan para investor untuk berinvestasi seperti yang terjadi di bursa efek yang didalamnya diperdagangkan saham-saham yang telah go public. Salah satu alasan para pengusaha memilih untuk menjadikan perusahaan menjadi go public adalah karena biaya modal yang rendah ( Ang, 1997). Keputusan penggunaan hutang haruslah menyeimbangkan antara keuntungan yang lebih besar dengan risiko yang lebih besar (Husnan, 2000:324).

Menurut Kasmir (2008:200), menyatakan bahwa net profit margin merupakan ukuran keuntungan yang membandingkan antara laba setelah bunga dan pajak dibandingkan dengan penjulan. Menurut Agus Sartono (2001:124) ROE adalah rasio yang dipengaruhi oleh besar kecilnya hutang perusahaan. Apabila proporsi hutang makin besar maka rasio ini akan makin besar pula. Secara fundamental, harga suatu saham dipengaruhi oleh kinerja perusahaan dan risiko yang dihadapi perusahaan. Kinerja perusahaan tercermin dari laba operasional dan laba 
bersih per lembar saham serta beberapa rasio keuangan yang menggambarkan kekuatan manajemen dalam mengelola perusahaan. Dengan kata lain, kinerja perusahaan dan risiko yang dihadapi dipengaruhi oleh faktor makro ekonomi dan mikro ekonomi. (Samsul, 2006:200).

\section{STUDI LITERATUR}

\section{Pengaruh Debt to Equity Ratio (DER) terhadap Harga Saham}

DER merupakan perbandingan antara total hutang dengan total modal sendiri. Rasio ini dipergunakan untuk mengukur tingkat penggunaan utang terhadap total modal yang dimiliki perusahaan. Semakin tinggi DER menunjukkan tingginya ketergantungan permodalan perusahaan terhadap pihak luar (hutang) sehingga beban perusahaan juga semakin berat. Dengan demikian dapat disimpulkan bahwa DER mempengaruhi harga saham perusahaan. Hipotesis yang diajukan dalam penelitian ini mengenai pengaruh Debt Equity Ratio (DER) terhadap harga saham adalah sebagai berikut :

\section{Pengaruh Net Profit Margin (NPM) terhadap Harga Saham}

Net profit margin atau margin laba bersih merupakan keuntungan penjualan setelah menghitung seluruh biaya dan pajak penghasilan. Margin ini menunjukan perbandingan laba bersih setelah pajak dengan penjualan. Hipotesis yang diajukan dalam penelitian ini mengenai pengaruh Net Profit Margin (NPM) terhadap harga saham adalah sebagai berikut :

\section{Pengaruh Return On Equity (ROE) terhadap Harga Saham}

ROE merupakan kemampuan suatu perusahaan dengan ekuitas (modal sendiri) yang bekerja didalamnya untuk menghasilkan laba bagi para pemegang saham. Dengan mengetahui besar-kecilnya ROE, pemegang saham dapat melihat keuntungan yang benar-benar akan diterima dalam bentuk dividen. Dengan demikian ROE dapat mempengaruhi harga saham.

\section{METODOLOGI}

Populasi dalam penelitian ini adalah industri keuangan sektor perbankan pada indeks LQ-45 yang terdaftar di Bursa Efek Indonesia tahun 2013-2018 dengan jumlah populasi sebesar 7 perusahan. Pengambilan sampel dengan metode purposive sampling. Kriteria yang digunakan dengan metode purposive sampling tersebut adalah Industri keuangan sektor perbankan pada indeks LQ-45 yang terdaftar di Bursa Efek Indonesia tahun 2013-2018, Perusahaan yang mempublikasikan laporan keuangan secara lengkap oleh secara berturut-turut selama tahun 2013-2018, Perusahaan yang tidak delisting dan re-listing di BEI antara 2013-2018, Saham aktif diperdagangkan di Bursa Efek Indonesia selama tahun 2013-2018. Menurut Surat Edaran Bursa Efek Jakarta No. SE-03/BEJ/II-1/1994, kriteria saham aktif yang diperdagangkan 
adalah saham yang mempunyai frekuensi perdagangan minimal 300 kali atau lebih dalam setiap tahunnya, Tidak mempunyai nilai ekuitas negatif. Data ini diambil dari laporan tahunan untuk menghitung Debt to Equity Ratio, Net Profit Margin, dan Return On Equity yang diperoleh dari situs resmi Bursa Efek Indonesia.

\section{Variabel Debt to Equity Ratio $\left(\mathbf{X}_{1}\right)$}

Menurut Munawir (2014:105) Debt to Equity Ratio (DER) digunakan untuk mengukur tingkat leverage (penggunaan hutang) terhadap total ekuitas yang dimiliki perusahaan. Debt to Equity Ratio (DER) dirumuskan sebagai berikut (Munawir, 214):

$$
\text { Debt to Equity Ratio }(D E R)=\frac{\text { Total Liabilitas }}{\text { Total Ekuitas }}
$$

\section{Variabel Net Profit Margin $\left(\mathbf{X}_{2}\right)$}

Net profit margin diukur dengan membandingkan laba bersih dengan penjualan bersih. Skala yang digunakan adalah skala rasio dan satuan ukur persentase. Dengan menggunakan rumus sebagai berikut :

$$
N P M=\frac{\text { Laba bersih }}{\text { Penjualan bersih }}
$$

\section{Variabel Return On Equity $\left(\mathbf{X}_{3}\right)$}

Return on equity diukur dengan membandingkan laba bersih dengan ekuitas. Skala yang digunakan adalah skala rasio dan satuan ukur persentase. Dengan menggunakan rumus sebagai berikut :

$$
\text { Return On Equity (ROE): } \frac{\text { Laba Bersih }}{\text { Ekuitas }}
$$

\section{Variabel Dependen (Y)}

Dalam penelitian ini variabel dependen yang digunakan adalah harga saham yang diperoleh dari Indonesian Capital Market Directory (ICMD) tahun 2013-2018. Harga saham pembukaan adalah harga pembukaan penawaran beli maupun jual atas saham yang diinginkan oleh penjual dan pembeli, yang merupakan patokan bagi order investor pada awal perdagangan.

\section{Model Analisis}

Analisis ini dilakukan untuk meneliti apakah ada hubungan sebab akibat antara ketiga variabel atau meneliti seberapa besar pengaruh debt to equity ratio, net profit margin, dan return on equity terhadap variabel dependen yaitu harga saham. Adapun rumus yang digunakan adalah: $\mathrm{Y}=\mathrm{a}+\mathrm{b}_{1} \mathrm{X}_{1}+\mathrm{b}_{2} \mathrm{X}_{2}+\mathrm{b}_{3} \mathrm{X}_{3}+\mathrm{e}$ 
$\mathrm{Y}=$ Harga Saham; $\mathrm{a}=$ Bilangan konstanta $\mathrm{X}_{1}=$ Debt to Equity Rasio; $\mathrm{X}_{2}=$ Net Profit Margin; $\mathrm{X}_{3}=$ Return On Equity; $\mathrm{e}=$ Standart error; $\mathrm{b}_{1}, \mathrm{~b}_{2}, \mathrm{~b}_{3}=$ Koefisien regresi untuk masing-masing variabel independen.

Menurut Ghozali (2012: 105) uji multikolinearitas bertujuan untuk menguji apakah suatu model regresi terdapat korelasi antar variabel bebas (independen). Pengujian multikolinearitas dilihat dari besaran VIF (Variance Inflation Factor) dan tolerance. Tolerance mengukur variabel independen yang terpilih yang tidak dijelaskan oleh variabel independen lainnya. Nilai cutoff yang umum dipakai untuk menunjukkan adanya multikolinearitas adalah nilai tolerance $\geq 0,01$ atau sama dengan nilai VIF $\leq 10$. Uji autokorelasi bertujuan menguji apakah dalam model regresi ada kolerasi antara kesalahan pengganggu pada periode-t dengan kesalahan pengganggu pada pada periode t-1 (sebelumnya). Pengujian autokolerasi dilakukan dengan uji durbin watson dengan membandingkan nilai durbin watson hitung (d) dengan nilai durbin watson tabel, yaitu batas atas (du) dan batas bawah (dL). Uji heteroskedastisitas bertujuan menguji apakah dalam model regresi terjadi ketidaksamaan varian dari residual satu pengamatan ke pengamatan yang lain. Jika varian dari residual satu pengamatan ke pengamatan lain berbeda, maka disebut heteroskedastisitas (Ghozali, 2012: 110)

\section{HASIL DAN PEMBAHASAN}

Berdasarkan hasil analisis, dengan memasukkan semua data maka didapatkan bahwa dari 34 data yang dimasukkan terdapat $34 \mathrm{~N}$ valid yang menunjukan data terproses semua. Dalam output terdapat nilai minimum harga saham 870 yang dimiliki oleh PT Bank Tabungan Negara, (Persero),Tbk. PT Bank Tabungan Negara, (Persero),Tbk merupakan Badan Usaha Milik Negara (BUMN) yang bergerak dibidang Perbankan untuk melayani dan mendukung pembiayaan sektor perumahan. Untuk nilai maksimum sebesar 26.000 yang dimiliki oleh PT. Bank Central Asia Tbk. PT. Bank Central Asia Tbk bergerak di bidang layanan perbankan komersial dimana aktivitas utamanya adalah mengumpulkan dana publik, menyalurkan kredit, dan pendapatan non bunga untuk ritel dan korporasi. Sedangkan nilai rata-rata (mean) sebesar 7560,5882.

Berdasarkan hasil, didapatkan bahwa dari 34 data yang dimasukkan terdapat $34 \mathrm{~N}$ valid yang menunjukan data terproses semua. Debt to Equity Ratio (DER) mempunyai nilai minimum 0,86 yang dimiliki oleh PT. Bank Pembangunan Daerah Jawa Barat Dan Banten Tbk. PT. Bank Pembangunan Daerah Jawa Barat Dan Banten Tbk adalah bank BUMD milik Pemerintah Provinsi Jawa Barat dan Banten. PT. Bank Pembangunan Daerah Jawa Barat Dan Banten Tbk adalah menjalankan kegiatan usaha di bidang perbankan dan membantu Pemerintah Provinsi, 
Kota/Kabupaten se-Jawa Barat dan Banten dalam membina Bank Perkreditan Rakyat (BPR) dan institusi jasa keuangan lainnya milik Pemerintah Provinsi, Kota/Kabupaten se-Jawa Barat dan Banten. Untuk nilai maksimum sebesar 11,40 dimiliki juga oleh PT. Bank Pembangunan Daerah Jawa Barat Dan Banten Tbk. Sedangkan untuk rata-ratanya sebesar 6,6150 dengan standar deviasi 2,61288. Dari paparan deskripsi diatas dapat disimpulkan bahwa perusahaan sektor keuangan pada indeks LQ45 mempunyai nilai rata-rata Debt to Equity Ratio (DER) sebesar 6,6150. Hal tersebut mencerminkan bahwa rata-rata hutang perusahaan emiten pada indeks LQ45 lebih kecil bila dibandingkan dengan nilai ekuitasnya dan proporsi hutang antar perusahaan relatif sama.

Tabel 1. Deskriptif Statistik

\begin{tabular}{cccccc}
\hline & $\mathbf{N}$ & Minimum & Maximum & Mean & Std. Deviation \\
\hline Harga & 34 & 870.00 & 26000.00 & 7560.5882 & 5900.39621 \\
Saham & & & & & \\
DER & 34 & .86 & 11.40 & 6.6150 & 2.20950 \\
NPM & 34 & .09 & .43 & .2656 & .09760 \\
ROE & 34 & .01 & .27 & .1516 & .05474 \\
\hline
\end{tabular}

Berdasarkan hasil analisis, dengan memasukkan semua data Net profit margin, maka didapatkan bahwa dari 34 data yang dimasukkan terdapat $34 \mathrm{~N}$ valid yang menunjukan data terproses semua. Net profit margin mempunyai nilai minumum 0,09 yang dimiliki oleh PT. Bank Pembangunan Daerah Jawa Barat Dan Banten Tbk. PT. Bank Pembangunan Daerah Jawa Barat Dan Banten Tbk adalah bank BUMD milik Pemerintah Provinsi Jawa Barat dan Banten. PT. Bank Pembangunan Daerah Jawa Barat Dan Banten Tbk adalah menjalankan kegiatan usaha di bidang perbankan dan membantu Pemerintah Provinsi, Kota/Kabupaten se-Jawa Barat dan Banten dalam membina Bank Perkreditan Rakyat (BPR) dan institusi jasa keuangan lainnya milik Pemerintah Provinsi, Kota/Kabupaten se-Jawa Barat dan Banten; nilai maksimum 0,43 yang dimiliki oleh PT. Bank Central Asia Tbk. PT. Bank Central Asia Tbk bergerak di bidang layanan perbankan komersial dimana aktivitas utamanya adalah mengumpulkan dana publik, menyalurkan kredit, dan pendapatan non bunga untuk ritel dan korporasi.; nilai rata-rata (mean) 0,2656; dan standar deviasi 0,09760. Dari paparan deskripsi diatas, maka dapat disimpulkan bahwa rata-rata perusahaan sektor keuangan di indeks LQ45 mempunyai nilai profit margin sebesar 0,2656 atau $26,56 \%$.

Dengan memasukkan semua data Return On Equity, maka didapatkan bahwa dari 34 data yang dimasukkan terdapat $34 \mathrm{~N}$ valid yang menunjukan data terproses semua. Return On Equity mempunyai nilai minumum 0,01 yang dimiliki oleh PT. Bank Pembangunan Daerah Jawa 
Barat Dan Banten Tbk. PT. Bank Pembangunan Daerah Jawa Barat Dan Banten Tbk adalah bank BUMD milik Pemerintah Provinsi Jawa Barat dan Banten. PT. Bank Pembangunan Daerah Jawa Barat Dan Banten Tbk adalah menjalankan kegiatan usaha di bidang perbankan dan membantu Pemerintah Provinsi, Kota/Kabupaten se-Jawa Barat dan Banten dalam membina Bank Perkreditan Rakyat (BPR) dan institusi jasa keuangan lainnya milik Pemerintah Provinsi, Kota/Kabupaten se-Jawa Barat dan Banten; nilai maksimum 0,27 yang dimiliki oleh PT Bank Rakyat Indonesia (Persero) Tbk. PT. Bank Rakyat Indonesia (Persero) Tbk merupakan Badan Usaha Milik Negara (BUMN) yang memberikan layanan perbankan, terutama pada segmen usaha mikro, kecil dan menengah (UMKM). nilai rata-rata (mean) 0,1516; dan standar deviasi 0,05474.

Tabel 2. Hasil Regresi Berganda

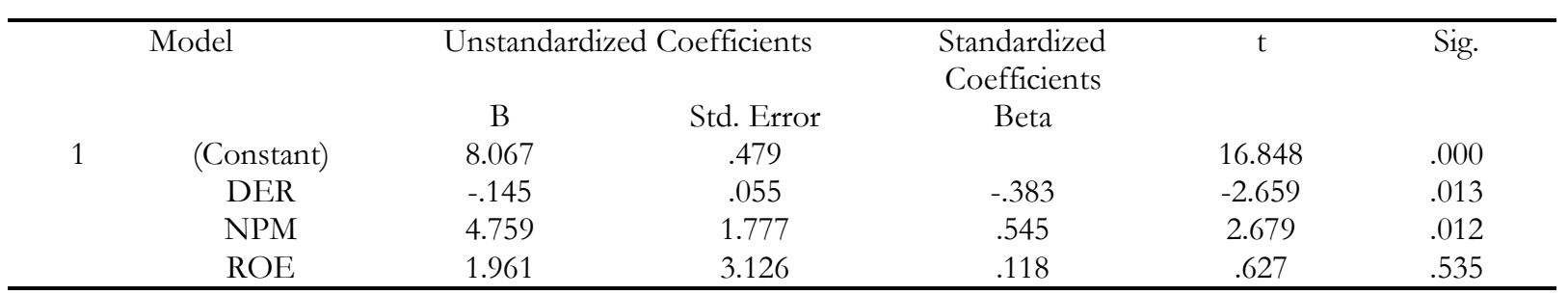

Konstanta sebesar 8,067 dapat diartikan bahwa besarnya harga saham akan meningkat sebesar 8,067 dengan asumsi Debt to Equity Ratio, Net Profit Margin, dan Return On Equity adalah nol (0). Debt to Equity Ratio mempunyai koefisien regresi dengan arah negatif terhadap harga saham sebesar -0,145. Hal ini dapat diartikan bahwa pengaruh Debt to Equity Ratio adalah berjalan tidak searah dengan harga saham, yaitu setiap adanya peningkatan Debt to Equity Ratio sebesar satu satuan maka akan terjadi penurunan pada harga saham sebesar 0,145, dengan asumsi Net Profit Margin dan Return On Equity konstan. Net Profit Margin mempunyai koefisien regresi dengan arah negatif terhadap harga saham sebesar 4,759. Hal ini dapat diartikan bahwa pengaruh Net Profit Margin adalah berjalan searah dengan harga saham, yaitu setiap adanya peningkatan Net Profit Margin sebesar satu satuan maka akan terjadi peningkatan pula pada harga saham sebesar 4,759, dengan asumsi Debt to Equity Ratio dan Return On Equity konstan. Return On Equity mempunyai koefisien regresi dengan arah positif terhadap harga saham sebesar 1,961. Hal ini dapat diartikan bahwa pengaruh Return On Equity adalah searah dengan harga saham, apabila terjadi peningkatan Return On Equity sebesar satu satuan maka akan diikuti kenaikan nilai perusahaan sebesar 1,961, dengan asumsi Debt to Equity Ratio dan Net Profit Margin konstan.

Berdasarkan Tabel 3. dapat dilihat bahwa tidak ada variabel yang memiliki nilai tolerance lebih kecil dari 0,01. Hasil pengujian juga menunjukkan semua variabel memiliki Variance 
Inflation Factor (VIF) lebih kecil dari 10. Hal ini berarti tidak ada masalah multikolonieritas pada model regresi.

Tabel 3. Tabel Deteksi Multikolinearitas

\begin{tabular}{|c|c|c|c|}
\hline \multicolumn{2}{|c|}{ Model } & \multicolumn{2}{|c|}{ Collinearity Statistics } \\
\hline & & Tolerance & VIF \\
\hline \multirow[t]{4}{*}{1} & (Constant) & & \\
\hline & DER & 496 & 2.017 \\
\hline & NPM & 248 & 4.038 \\
\hline & ROE & .288 & 3.467 \\
\hline
\end{tabular}

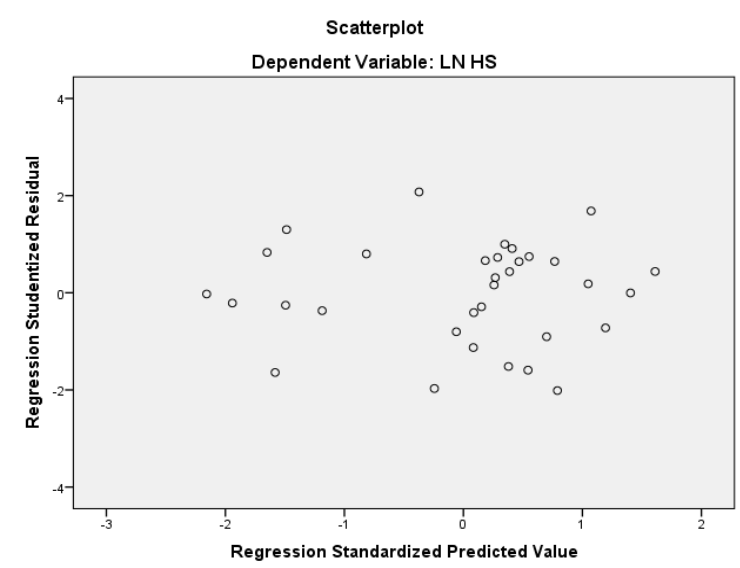

Gambar 1. Hasil Uji Scatterplot

Berdasarkan Gambar 1. dapat dilihat bahwa titik-titik menyebar secara acak serta tersebar (tidak membentuk pola tertentu) baik di atas maupun dibawah angka 0 (nol) pada sumbu Y. Hal ini dapat disimpulkan bahwa tidak terjadi heterokedastisitas pada model regresi.

Tabel 4. Hasil Uji Glejser

\begin{tabular}{|c|c|c|c|c|}
\hline \multicolumn{2}{|c|}{ Model } & $\begin{array}{c}\text { Standardized Coefficients } \\
\text { Beta }\end{array}$ & $\mathrm{t}$ & Sig. \\
\hline 1 & (Constant) & & 2.183 & .037 \\
\hline & DER & -.219 & -.841 & .407 \\
\hline & NPM & -.159 & -.432 & .669 \\
\hline & $\mathrm{ROE}$ & .095 & .280 & .781 \\
\hline
\end{tabular}

Berdasarkan Tabel 4. dapat diilihat bahwa uji glejser dengan tingkat signifikansi 0,05 menunjukkan bahwa data memiliki signifikansi di atas 0,05 . Hal ini berarti model regresi tidak mengandung heterokedastisitas. Berdasarkan Tabel 5 diperoleh nilai Durbin-Watson sebesar 2,003, dengan level of signifikan 5 persen, untuk $\mathrm{n}=34$ dan jumlah variabel bebas $(\mathrm{k})$ sebanyak $3, \mathrm{~d}_{\mathrm{L}}=1,33251$ dan $\mathrm{d}_{\mathrm{U}}=1,58045$. Nilai Durbin-Watson terletak antara $\mathrm{d}_{\mathrm{U}} \mathrm{dan} 4-\mathrm{d}_{\mathrm{U}}(1,58045<$ $2,003<2,41955)$ maka dapat disimpulkan tidak terdapat autokorelasi. 


\begin{tabular}{|c|c|c|c|c|c|c|c|c|c|c|}
\hline \multicolumn{11}{|c|}{ Tabel 5. Hasil Uji Autokorelasi } \\
\hline \multirow[t]{3}{*}{ Model } & \multirow[t]{3}{*}{$\mathrm{R}$} & \multirow{3}{*}{$\begin{array}{l}\mathrm{R} \\
\text { Square }\end{array}$} & \multirow{3}{*}{$\begin{array}{l}\text { Adjusted } \\
\text { R Square }\end{array}$} & \multirow{4}{*}{$\begin{array}{l}\text { Std. } \\
\text { Error of } \\
\text { the } \\
\text { Estimate }\end{array}$} & \multicolumn{2}{|c|}{ Change Statistics } & \multirow{3}{*}{ df1 } & \multirow{3}{*}{ df2 } & \multirow{3}{*}{$\begin{array}{l}\text { Sig. F } \\
\text { Change }\end{array}$} & \multirow{3}{*}{$\begin{array}{l}\text { Durbin- } \\
\text { Watson }\end{array}$} \\
\hline & & & & & $\mathrm{R}$ & $\mathrm{F}$ & & & & \\
\hline & & & & & Square & Change & & & & \\
\hline 1 & $.838^{a}$ & .702 & .672 & & $\begin{array}{l}\text { Change } \\
.702\end{array}$ & 22.823 & 3 & 29 & .000 & 2.003 \\
\hline \multicolumn{11}{|c|}{$\begin{array}{l}\text { a. Predictors: (Constant), ROE, DER, NPM } \\
\text { b. Dependent Variable: LN HS }\end{array}$} \\
\hline
\end{tabular}

\section{Debt to Equity Ratio}

Debt to Equity Ratio merupakan proporsi struktur modal antara hutang dan ekuitas. Berdasarkan hasil perhitungan analisis regresi, hasilnya menunjukan bahwa nilai koefisien dalam persamaan regresinya Debt to Equity Ratio mempunyai nilai -0,145; sedangkan nilai signifikansi $0,013<0,05$ atau $\mathrm{t}$ hitung $-2,659<\mathrm{t}$ tabel 1,699 yang berarti bahwa Debt to Equity Ratio mempunyai pengaruh negatif signifikan terhadap harga saham. Bagi setiap perusahaan untuk menentukan proporsi struktur modal mempunyai target yang berbeda-beda, Jika tingkat hutang yang masih berada dibawah target mungkin perlu dilakukan ekspansi dengan melakukan pinjaman, sementara jika melampuai target perusahaan dapat melakukan penjualan saham. Dalam pengambilan keputusan untuk menentukan proporsi struktur modal akan melibatkan trade off theory, semakin besar hutang yang digunakan untuk membiayai operasional perusahaan maka risiko yang melekat pada perusahaan juga semakin besar.

Pada perusahaan di industri keuangan sektor perbankan periode tahun 2013-2018 yang menyatakan bahwa Debt to Equity Ratio mempunyai pengaruh negatif tidak signifikan terhadap harga saham. Sesuai yang dikemukakan oleh Husnan (2000) bahwa bagi investor risiko yang tinggi (penambahan hutang) akan membuat expected return semakin tinggi. Jadi bagi investor yang suka dengan risiko akan menilai bahwa penambahan hutang merupakan ekspansi dari perusahaan untuk meningkatkan laba. Namun ada tipe investor yang defensive atau menghindari risiko (Hartanty, 2011) dan berasumsi bahwa penambahan modal akan menambah beban bunga dan mengurangi jumlah dividen yang diterima (Sugiarto dan Khusaini, 2014). Adanya perspektif ganda dari investor terhadap debt to equity ratio tersebut membuat harga saham hanya sedikit merespon. Penelitian ini sesuai dengan penelitian yang dilakukan Puspita (2013) dan Malintan (2013).

\section{Net Profit Margin}

Net profit margin adalah mengukur profitabilitas yang berkaitan dengan penjualan yang dihasilkan, penghasilan bersih penjualan. Net profit margin atau margin laba bersih merupakan keuntungan penjualan setelah menghitung seluruh biaya dan pajak penghasilan. Margin ini 
menunjukan perbandingan laba bersih setelah pajak dengan penjualan. Berdasarkan hasil perhitungan analisis regresi, hasilnya menunjukan bahwa nilai koefisien dalam persamaan regresinya Net Profit Margin mempunyai nilai 0,080; sedangkan nilai signifikansi 0,012<0,05 atau $\mathrm{t}$ hitung 2,679 > t tabel 1,699 yang berarti bahwa Net Profit Margin mempunyai pengaruh positif signifikan terhadap harga saham. (Tandelilin, 2008: 239) dalam jurnal Hutami (2012) NPM yang tinggi dapat menunjukkan kinerja perusahaan yang bagus karena dapat menghasilkan laba bersih yang besar melalui aktivitas penjualannya sehingga saham perusahaan tersebut banyak diminati investor dan akan menaikkan harga saham perusahaan tersebut.

Apabila rasio NPM perusahaan besar maka menunjukan bahwa perusahaan berkinerja dengan baik, karena dapat menghasilkan laba bersih yang besar melalui aktifitas penjualannya, sehingga digunakan investor dalam mengambil keputusan apakah membeli saham emiten tersebut, karena laba bersih yang meningkat berpengaruh pada minat investor untuk menginvestasikan dananya di perusahaan tersebut, yang pada akhirnya akan menyebabkan harga saham perusahaan tersebut meningkat. Penelitian yang menyatakan bahwa tedapat pengaruh signifikan antara net profit margin terhadap harga saham telah dibuktikan oleh Pasaribu (2008), Anwar (2009), Rianti (2010), Hutami (2012) hasil penelitian menunjukan bahwa net profit margin memiliki pengaruh yang signifikan terhadap harga saham.

\section{Return On Equity}

ROE disebut juga dengan laba atas equity. Di beberapa referensi disebut juga dengan rasio total asset turnover atau perputaran total aset. Rasio ini mengkaji sejauh mana suatu perusahaan mempergunakan sumber daya yang dimiliki atau mampu memberikan laba atas ekuitas. ROE merupakan rasio laba bersih terhadap ekuitas biasa, mengukur tingkat, pengembalian atas investasi pemegang saham biasa.

Menurut Chrisna (2011: 34) dalam jurnal Hutami (2012) kenaikan return on equity biasanya diikuti oleh kenaikan harga saham perusahaan tersebut. Semakin tinggi ROE berarti semakin baik kinerja perusahaan dalam mengelola modalnya untuk menghasilkan keuntungan bagi pemegang saham. Dapat dikatakan bahwa perusahaan tersebut dapat menggunakan modal dari pemegang saham secara efektif dan efisien untuk memperoleh laba. Dengan adanya peningkatan laba bersih maka nilai ROE akan meningkat pula sehingga para investor tertarik untuk membeli saham tersebut yang akhirnya harga saham perusahaan tersebut mengalami kenaikan. Penelitian atas pengaruhnya return on equity terhadap harga saham telah dibuktikan oleh Pasaribu (2008), Rianti (2010), Dini dan Indarti (2010), Hutami (2012), Thim (2012) hasil penelitian menunjukan bahwa return on equity memiliki pengaruh yang signifikan terhadap harga saham. Berdasarkan hasil perhitungan analisis regresi perusahaaan-perusahaaan sektor keuangan 
pada indeks LQ45 tahun 2013-2018, hasilnya menunjukan bahwa nilai koefisien dalam persamaan regresinya return on equity mempunyai nilai 1,961 ; sedangkan nilai signifikansi 0,535 $>0,05$ atau thitung 0,627 < tabel 1,699 yang berarti bahwa return on equity tidak mempunyai pengaruh yang signifikan terhadap harga saham. Semakin tinggi nilai ROE, tentunya akan menarik minat para investor untuk menanamkan modalnya pada perusahaan bersangkutan karena mengindikasikan bahwa perusahaan tersebut mempunyai kinerja yang baik dan akibatnya harga saham pun akan ikut tinggi.

\section{Simpulan}

Berdasarkan hasil penelitian yang telah dilakukan mengenai pengaruh debt to equity ratio, net profit margin dan return on equity terhadap harga saham pada perusahaan sektor keuangan indeks LQ-45 yang terdaftar di Bursa Efek Indonesia (BEI) periode tahun 2013-2018, maka dapat disimpulkan beberapa hal sebagai berikut : Berdasarkan hasil penelitian diperoleh bahwa DER memiliki hubungan negatif dan berpengaruh secara signifikan terhadap harga saham, sehingga hipotesis pertama diterima. Berdasarkan hasil penelitian diperoleh bahwa NPM memiliki hubungan positif dan berpengaruh secara signifikan terhadap harga saham, sehingga hipotesis kedua diterima. Berdasarkan hasil penelitian diperoleh bahwa ROE tidak berpengaruh secara signifikan terhadap harga saham, sehingga hipotesis ketiga ditolak. DER, NPM, dan ROE secara bersama-sama atau simultan berpengaruh signifikan terhadap harga saham. Hasil perhitungan koefisien determinan $\left(\mathrm{R}_{2}\right)$ sebesar 0,672. Hal ini menunjukkan bahwa variabel DER, NPM dan ROE dapat menjelaskan harga saham sebagai variabel dependen sebesar 67,2\%.

Bagi peneliti selanjutnya, model penelitian ini masih menghasilkan pengaruh yang kurang kuat terhadap harga saham yang hanya $67,2 \%$ jadi diharapkan untuk penelitian selanjutnya dapat menambahkan variabel independen mikro dan makro ekonomi sehingga model penelitian dapat berpengaruh kuat terhadap variabel dependen. Peneliti diharapkan menambah sektor perusahaan, indeks syariah atau indeks-indeks unggulan di BEI seperti indeks ISSI, SMInfra18, dan indeks lainnya. Selain itu, tahun pengamatan juga dapat di perpanjang supaya mendapatkan hasil yang lebih akurat.

\section{Referensi}

Agus, Sartono 2001. Manajemen Keuangan Teori dan Aplikasi edisi ke empat.Yogyakarta BEF. Ang, Robert. 1997. Buku Pintar Pasar Modal Indonesia (The Intelligent Guide to Indonesian Capital Market). Jakarta: Mediasoft Indonesia. 
Ghozali, Imam. 2012. Aplikasi Analisis Multivariate dengan Program IBM SPSS. Yogyakarta: Universitas Diponegoro.

Kasmir. (2008). Bank dan Lembaga Keuangan Lainnya. Jakarta: PT. Raja Grafindo Persada.

Samsul, Muhamad. 2006. Pasar Modal Dan Manajemen Portofolio. Penerbit Erlangga. Surabaya.

Suad Husnan. (2000). Manajemen Keuangan Teori dan Penerapan, Edisi Ketiga. Yogyakarta: UPP AMP YKPN.

Sunariyah. 2006. Pengantar Pengetahuan Pasar Modal, Edisi 5. Yogyakarta: UPP AMP YKPN.

Laporan Keuangan Harga Saham.www.idx.co.id. Diambil pada tanggal 01 Januari 2019 